\title{
COMPETITIVE ADVANTAGE FROM OPERATIONAL CORPORATE REAL ESTATE DISPOSALS
}

\author{
Antti LOUKO \\ Helsinki University of Technology, Real Estate Studies, P.O. Box 1200, FIN-02015 HUT, Finland \\ Tel.: +358 9451 3877; fax. +358 9465 077; e-mail: ajlouko@cc.hut.fi
}

Received 23 January 2004; accepted 19 March 2004

\begin{abstract}
The large-scale operational corporate real estate disposals, which have lately become more and more common in Europe, can create many benefits to corporations. Firstly, the corporations can get an immediate capital injection without additional external financing to support growth or to better capital structure. Secondly, corporations can in the best case obtain more property industry knowledge, economies of scale, tax advantages and increased flexibility through property disposals. However, it is also important to notice that sometimes the best expert is an internal property manager and that large corporate real estate deals can be slow and costly to structure. Furthermore, if the outsourcing is not planned well, agency problems and inflexibility could arise. In addition, off-balance sheet financing is becoming more difficult due to changes in accounting rules. In all, it is crucial to have a solid property strategy that supports the overall business goal before structuring large-scale disposals.
\end{abstract}

KEYWORDS: Corporate real estate; Sale and leaseback; Disposal; Advantage; Value

\section{INTRODUCTION}

Throughout the history there has been a vigorous debate on the importance of shareholder value relatively to other measures such as employment, social responsibility and the environment when valuating corporations and their success (Copeland, Coller, Murrin 2000). This debate has usually been cast in terms of shareholder versus stakeholder value ${ }^{1}$. According to Nappi-Choulet (2002), until the mid-90s shareholder value management had only little influence on corporate management practices in many continental and northern European countries and a large part of the corporations still had a strong stakeholder-oriented corporate governance culture. However, because of the European economical and political integration process, the cross-border investment activity increased significantly and led to an important growth in the proportion of AngloSaxon investment capital in the continental
European and Nordic corporations. NappiChoulet (2002) indicates that when Anglo-Saxon investment capital flooded in to the continental and northern European corporations, it meant a rapid change from the traditional stakeholder corporate governance culture towards a more shareholder-oriented governance model. When at the same time total amount of financial capital was growing rapidly, the change was very fast (Table 1 ).

Real estate is still often one of the last business areas inside European corporations not yet affected by this growing pressure from the shareholders and financiers. According to many studies, corporate real estate assets are still often undermanaged, which is why it has not been a surprise that many corporations have begun selling their real estate assets and outsourcing related services. In the US, a large part of the corporations have already gone through a similar process of restructuring real estate holdings and have today in average much 
Table 1. Volume of financial assets of institutional investors, Billion USD

\begin{tabular}{lllll}
\hline & \multicolumn{2}{l}{ Institutional Investors } & \multicolumn{2}{l}{ Pension Funds } \\
\cline { 2 - 5 } & $\mathbf{1 9 9 2}$ & $\mathbf{1 9 9 9}$ & $\mathbf{1 9 9 2}$ & $\mathbf{1 9 9 9}$ \\
\hline Netherlands & 427.4 & 799.4 & 244.8 & 448.5 \\
UK & $1,207.2$ & $3,264.8$ & 552.4 & $1,226.3$ \\
France & 800.6 & $1,695.7$ & & \\
Germany & 665.2 & $1,529.0$ & 56.6 & 63.3 \\
Spain & 117.5 & 370.1 & 14.4 & 12.8 \\
Italy & 225.3 & $1,078.4$ & 38.3 & 33.2 \\
Sweden & 187.3 & 322.4 & 3.9 & \\
EU total & $3,916.6$ & $9,832.9$ & 942.2 & $1,858.0$ \\
US & $8,035.3$ & $19,279.0$ & $3,011.2$ & $6,900.8$ \\
\hline Total OECD & $\mathbf{1 6 , 0 3 3 . 5}$ & $\mathbf{3 6 , 1 4 7 . 3}$ & $\mathbf{4 , 8 2 8 . 8}$ & $\mathbf{1 0 , 3 0 5 . 9}$ \\
\hline
\end{tabular}

Source: OECD

less property assets on balance sheet than corporations in Europe (Table 2).

\subsection{Evidence from the markets}

The amount of real estate disposals in Europe has been increasing heavily during the past few years. Appendix 1 lists the major sale and lease back transactions of operational corporate real estate in Europe during the last five years. Over $1 / 3$ of the value of these transactions has been made by corporations in the IT / telecommunications sector that have been wrestling with huge amounts of debt since the auctions of the Universal Mobile Telecommunication System (UMTS) permits. In a survey conducted by Rodney (2000), in addition to telecommunications corporations, also three other business sectors were mentioned as most likely

Table 2. Corporations' real estate ownership in the US and in Europe (Nappi-Choulet 2002)

\begin{tabular}{lll}
\hline & $\begin{array}{l}\text { CRE on balance } \\
\text { sheet/ Total assets }\end{array}$ & $\begin{array}{l}\text { CRE on balance } \\
\text { sheet / All CRE }\end{array}$ \\
\hline USA & approx. 15\% & approx. 30\% \\
Europe & approx. 35 - 40\% & approx. 70\% \\
\hline
\end{tabular}

to rationalize their operational property holdings in the near future. The other categories were hotels, brewers and stores.

There has, indeed, been a clear trend in hotel business towards separating the hotel ownership from hotel management, which can also be seen in the appendix 1. There have been signs that hotel operators with less real estate on balance sheet grow faster than corporations with large property holdings. On the other hand, in some stock exchange listed retail corporations that have a large operational freehold property base, the value of the real estate holdings has sometimes exceeded market capitalization of the corporation as for instance Wainwright (2000) showed. This has made them possible take over targets and some take over attempts have been seen during the past few years. According to Manning, Rodriguez and Roulac (1997) a company with a competency in corporate real estate asset management, which can unlock cost efficiencies and create strategic advantages, may be in the position to profitably acquire companies that do not possess this corporate management knowledge and expertise. Thus, corporate real estate restructurings could drive merger and ac- 
quisition success. Retail corporations have become the second largest group of companies, which have been carrying out large real estate portfolio sale and leaseback transactions in Europe during the past few years when it come to the total value of the deals (see appendix 1).

Nevertheless, it is interesting to notice that majority of the companies that have been carrying out large-scale sale and leasebacks are former or current governmental corporations (among others, governmental airline, energy, railway, postal and telecommunications corporations). It is clear that shareholder value has not always been the main concern for the governmental organizations and corporations. Therefore, today, when many governments are privatizing their ownerships, it is at the latest the new shareholders, who make the management to try to enhance shareholder value in every way.

\section{RESEARCH PROBLEM, METHODOLOGY AND DATA}

This paper discusses the main advantages and disadvantages of operational corporate real estate disposals and outsourcings on the basis of the findings in previous scientific literature and studies. The paper reviews a large amount of research related to corporate real estate management and finance. It also describes the main techniques and ways to carry out operational corporate real estate disposals and outsourcings. In addition, it presents some new evidence concerning the increased activity in the European real estate sale and leaseback market. The study answers on the following questions. What are the main advantages and disadvantages of operational corporate real estate disposals and outsourcings? What are the most commons ways and techniques available to carry out these disposals and outsourcings?

There are a lot of published papers and other academic research done of corporate real estate management and real estate buy vs. lease decisions. However, most of this research is done and published in the US. The US real estate researchers started to publish papers and show more interest on corporate real estate management issues already in the early 1980 s and since then the amount of published papers in this field has risen steadily when corporate real estate's important role as one of the corporations' main resources has been recognized. In Europe, corporate real estate thinking has much shorter roots. Especially in most of the continental and northern European countries the shareholder value and strategic corporate real estate management thinking were widely adapted only in the mid-1990s. This can be seen also in the corporate real estate management literature and research, which is relatively new in Europe. Most of the European corporate real estate research is only from the 1990 s or from this decade and usually done in the UK. However, some significant corporate real estate research has also been done in the Netherlands, France and Germany. However, there is still a clear lack of corporate real estate research in the continental and northern Europe, although at the same time majority of the corporations in these countries are currently reconsidering their need to own real estate and at the same restructuring and developing their real estate management functions.

The literature studied in this paper has been chosen by going through a large amount of the most significant research in the European and North American academic journals of this field. The literature that has been reviewed concentrates mostly on corporate real estate and shareholder value management and real estate finance.

\section{CORPORATE VALUE FORMATION AND REAL ESTATE}

\subsection{Theoretical valuation of corporations}

In order to create wealth, managers must either increase the current or the expected after-tax cash flows of the company or reduce the firm's overall risk with the same level of income. As we know, the value of a corpora- 
tion cannot be increased or decreased by changing financing methods, if these decisions do not alter the real production process. This should apply also to real estate leasing vs. ownership decisions, if the lease of an asset is a strict financial net lease, which is a pure substitute for debt (Stulz and Johnson 1985), even though it might enhance corporation's key performance figures. Therefore, the possibility to add value by leasing should originate rather from the fact that some real estate market operators can manage real estate and related risks more efficiently than others (for example Benjamin, de la Torre and Musumeci 1998).

Nevertheless, the situation in the real world is rarely simple as that. In fact, corporate management faces all the time different real options (such as growth) that may in theory increase (or decrease) corporation's market value. When analyzing investment possibilities with the so-called internal rate of return criterion (IRR), a company should accept all the investments that have an IRR greater than its opportunity cost of capital (Copeland and Weston 1992). Therefore, if a company can invest in its businesses with a higher rate of return than its cost of capital, it should invest in order to create more value. Thus, we must add that financing real estate by leasing can be logical if the corporation can invest the money that is saved with higher IRR than its weighted average cost of capital (WACC) and if, at the same time, the leasing is not much more expensive and does not create major additional risks.

One of the best-known methods for analyzing the effectiveness of a firm's capital spending is to measure the economic value added (EVA). EVA is a measure of economic profits, which subtracts a company's cost of capital (equity and debt) from its net operating profits before tax. A positive EVA implies a firm is earning a return on its investments that exceeds the cost of funds used to fund those investments, while a negative EVA suggests that a firm is destroying investment capital (Megginson 1997).

Thus, we can say that a corporation can cre- ate value by selling and leasing back its operational real estate if:

1. the leasing decision cuts the corporation's running costs (and it does not create major additional risks),

2 . by leasing the corporation is less risky from shareholders point of view (and at the same time it does not create major additional costs) or

3. if by leasing instead of owning corporation can redirect the capital preserved to investments that yield more than the corporation's WACC.

\subsection{Corporate real estate and market value}

Even though the value of a company can in theory be seen as a relation between its future cash-flows and the company's cost-of-capital, there are still many other practical factors influencing on a company's performance in the stock markets. Chen, Conover and Kensinger discuss how Woolridge (1995) provided evidence that more than half of the value of a stock is typically based upon something besides the next five years' expected earnings. Thus, the present value of growth opportunities or expectations of receiving a premium price when selling the shares account for large part of the share value. Chen, Conover and Kensinger found five practical ways for management to create value, some of which have no direct relationship with company's profit expectations or risk-level.

1. Find investment opportunities that bear the market (create EVA). However, the main problem is not the difficulty to bear the market, but rather to need to do better than expected, which is needed to enhance the market capitalization.

2. Reduce resources committed to activities that lack the competitive advantage (in the language of real options, exercising abandonment puts).

3. Pay out cash, when management cannot find competitive investment opportunities (that do not create EVA). 
4. Spin-off any business units or asset pools that can stand by themselves (preparing for the possibility of a spin-off involves creating new options).

5 . Be acquired by another company.

Some studies have been done of real estate asset sale and leaseback and spin-off impact on the corporate market values. For example, Slovin, Sushka and Polonchek (1990) studied asset sale and leasebacks in the US between 1975-1986 and found out that two-day average abnormal return was 0,85\%. Slovin, Sushka and Polonchek (1990) suggested that the positive market perception results from an overall reduction in the present value of expected taxes. Similarly, Rutherford (1990) studied a sample of 41 sale and leasebacks between 1980-1987 in the US and found out that the sale and leasebacks of real estate had substantial benefits for seller-lessees (abnormal return of 1.59\%). However, Alvayay, Rutherford and Smith (1995) reported of their study of sale and leasebacks that the seller-lessee accrued positive abnormal returns only prior the US Tax Reform Act of 1986, which supports the Slovin, Sushka and Polonchek (1990) hypothesis that the positive market perception was result from an overall reduction in the present value of expected taxes.

It is interesting to notice that there is not any similar event-studies of sale and leaseback effect on corporate value made based on a European sample of corporations, and that all of the event-studies made in the US are rather old. Therefore, we do not know what the sale and leaseback effect would be nowadays and especially what it would be in Europe. However, it is very interesting to notice that there is empirical evidence that stock price reactions to announcements of both equity and debt type issues are generally non-positive.

At least, Hite, Owers and Rogers (1984) and Ball, Rutherford and Shaw (1993) have noticed that by spinning off corporate real estate corporations could similarly gain abnormal returns for their shareholders. In this case spin-off means a formation of subsidiary to own and control parent company's real estate. The newly created shares of the subsidiary are then distributed to the original stockholders and the subsidiary operates independently. In the case of operational corporate real estate a spin-off would mean an arrangement very near a sale and leaseback. According to John (1993), spinoffs increase shareholder wealth by reducing agency costs and increasing the value of taxshields. Rodriquez and Sirmans (1996) suggest that in corporate real estate sell-offs and spinoffs, the value increase is consistent with the hypothesis that firm values increase when information regarding real estate asset values is provided to the market.

By using standard study methodology, Rutherford and Nourse (1988) have showed that the formation of a corporate real estate unit is, in general, also associated with positive gains to shareholders. The largest gains were associated with the publicly traded subsidiaries and the second largest gains were associated with the master limited partnerships and the wholly owned subsidiaries. Rutherford and Nourse (1988) say that the reasons given to the decisions to form separate real estate units are 1) cost control 2) income generation 3) suspected under valuation of real estate 4) special characteristics of real estate 5) risk reduction and 6) tax benefits. Rutherford's and Nourse's findings are consistent with the claim that real estate assets have been underutilized and that active management of real estate is the responsibility of the firm if it intends to maximize the shareholder wealth.

Allen, Rutherford and Springer (1993) were able to show some evidence that in leasing decisions of corporate real estate, the lessee firm accrues positive abnormal returns. In addition, there is evidence that the corporations that have less real estate holdings on their balance sheet trade at higher share price than similar companies with more real estate holdings (for example Kuruvilla 1994).

Glascock, Davidson and Sirmans (1989) studied acquisitions and dispositions of real estate by non-real estate firms from 1981 to 1986 . 
Contrary to previous studies of corporate real estate, they found no abnormal return associated with the buyers of real estate and only a weak evidence of excess returns from sellers. Glascock, Davidson and Sirmans (1989) suggest that when acquisition or disposition of a realty asset has no change in the management structure of the asset, no excess return can be found as in their study.

\subsection{Real estate asset management and corporate value}

Based on Jonge (1996) Krumm (1999) introduces seven ways, in which corporate real estate function can contribute to corporate value formation. Corporate real estate management can add shareholder value by increasing productivity, reducing costs, more efficient risk control, increase of asset values, increasing flexibility, developing the workplace culture and by working for better corporate image (public relations and marketing).

Because corporate real estate is often relatively inefficiently managed, there can be good prospects to add corporations' value through efficient cost control. Occupancy costs directly affect the net earnings of the firm and are usually the second largest single running cost in a corporation after personnel costs. For example Booth (1999) indicates that a reduction in occupancy costs of $2 \%$ can boost the profit margin by nearly $10 \%$, even when net sales are constant.

In addition, corporate real estate can increase corporate revenue streams by making corporate real estate to serve better the corporate goals with efficient facilities and asset management. Corporate real estate can, for instance, help in creating better and more efficient working environments that can decrease absences of leave and support the company image. In addition, it can be possible to get additional gains from corporate real estate with successful buy, sell and other financial decisions. Also appropriately selected sites and corporate facility locations can help significantly in increasing corporate profit margins. Effective corporate real estate management can also help to control corporate risks by making corporate real estate portfolio more flexible and by for example decreasing environmental risks and labor conditions.

According to Krumm (1999) real estate managers have to focus all the time more on the interests of the corporate stakeholders. The internal corporate real estate organization must be able to prove its 'raison d'être'. Thus, it must be able to add corporate value more efficiently than external service providers that are nowadays available almost in every market.

Outsourcing of corporate real estate management tasks can also be based on the assumption that it is an easy way to rationalize property costs and at the same time get additional occupational flexibility. According to Nappi-Choulet (2002) by focusing on its core business the company has a much clearer picture of its own comparative advantages. It can re-organize its value chains, focus its activities on its most profitable business segments and enhance the value of its expertise compared to its competitors. Such strategy allows a company to transfer risks not associated with its core business to a service provider who is best placed to take risks because property is his area of expertise. Nevertheless, as Manning, Rodrigues and Roulac (1997) have put it, outsourcing can benefit stockholders only if outside contractors can carry out functions more efficiently than internal personnel and at the same time the outsourcing gain must be large enough to allow the outside service providers to make an adequate profit. They add that primary source of possible efficiency gains in outsourcing stems from economies of scale and scope and from real estate reporting improvements (incl. timely valuations etc.). According to Manning, Rodriguez and Roulac (1997), the management functions that are more likely to be carried out more effectively by internal managers are the more strategic capability levels that also have the greatest impact on corporations' value. 


\section{CORPORATE REAL ESTATE FINANCE}

\subsection{To lease or to own?}

As we mentioned before, there have been indications that the capital markets, on average, have reacted positively to real estate lease announcements. However, this supports more the hypothesis that corporate management is continuously trying to enhance shareholder wealth than the hypothesis that it would usually be more appropriate to lease than own property. According to, for instance, Rodriguez and Sirmans (1996), Leasing may or may not be the optimal strategy depending on the specific circumstances.

Based on Krzysko and Marciniak (2001), we can summarize that financing options of corporate real estate are influenced by a number of factors at the corporate and the real estate management function levels. These are, among others, corporate debt rates, shifts within the company, corporation's size and growth pace, the use and the location of the property and the current real estate and construction cycle situations. Nevertheless, as Krumm (1999) wrote, instead of focusing on maximizing wealth in real estate investments or simply concentrating on the technical state of properties, the corporate real estate manager's opportunities to maximize return on investment are controlled by, and must conform to, the business of the corporation. Thus, all that matters is the activities on corporation's core business segments, which means in practice also that corporation's real estate finance decisions should originate from the overall corporate business aim and the possible gains that can be obtained from the real estate markets should be considered only as a welcomed byproduct. Thus, some researchers have suggested that, it should be in some cases, appropriate to leave the real estate ownership, risks and management tasks to real estate professionals and concentrate on the corporate core activities. But what is it that makes an external real estate professional sometimes better in real estate management and ownership than an internal expert? For instance, Glascock, Davidson and Sirmans (1989) suggested that it is only the changes in management structures of real estate that can lead to excess returns for shareholders in real estate disposals.

Benjamin, de la Torre and Musumeci (1998) suggested that real estate investor's ability to run real estate business better stems primarily from the possible economies of scale obtained when managing a large real estate portfolio, possible savings in taxes, possible better access to credit markets and possible comparative advantage in asset acquisition and disposal by better market knowledge. Of course, these gains of outsourcing should be large enough to allow the investor to make an adequate profit, which means somewhat higher direct costs. In addition, there are also other issues that could make leasing expensive. For example, Lewellen, Long and McConnell (1976), Miller and Upton (1976) and Myers, Dill and Bautista (1976) have written about the asset-abuse problem. In theory, there could be some over-utilization of rental property by the tenant, which would then be reflected as higher rents. Furthermore, many researchers have written about the possible agency problems that might arise between service subscriber (in this case the tenant) and the service provider (the owner / manager).

It is general knowledge that when done correctly, leasing can also create other advantages for corporation's businesses. One of the most talked-about benefits is the increased flexibility that could be obtained with leases of different length, options and break-clauses, which could also decrease risks associated with real estate holdings. Furthermore, by leasing a corporation can release $100 \%$ of property's market value to support its core businesses, which is not possible with secured lending, for instance. In addition, leasing can decrease corporate risks by diversifying its funding sources. Today, one additional key-advantage is that in most countries neither the rental liability nor the asset is shown in the balance sheet in leasing arrangements, which makes corporation's 
key performance ratios look better than when the asset is owned. However, this is about to change in the future.

Many researchers have suggested that leasing instead of owning would mean loss of control over the facilities and the possible future capital gain. However, it can be similarly argued that there are today leasing methods that allow, in theory, nearly as solid a control over the facilities as a traditional ownership. In addition, by creating innovative structures (joint ventures, option structures) it is also possible to get a stake in the future capital gain of the property. Manning (1991) suggested already in 1991 that there was a trend toward corporate leases with equity residual interests. Therefore, the question should be more, if the cost of transferring risks to service providers is smaller than the gain that is obtained this way. However, it is also important to keep in mind that a corporation can never fully avoid the property market related risks, even if it outsourced all of its property holdings and related tasks, as long as it has facilities for which it pays rent.

It is clear that corporate real estate often needs multiple strategies because of the multiple factors concerning products and markets that need to be supported (Nourse and Roulac 1993). Therefore, it is similarly clear that the optimal technique to finance corporate real estate differs between asset types and uses as for example Krzysko and Marciniak (2001) have showed and that several real estate financing techniques are usually needed.

In general, arguments for and against leasing are:

+ generally off-balance sheet (from both sides of the balance sheet),

+ diversifies financing sources,

+ rental payments are tax allowable,

+ release $100 \%$ of value,

+ market / residual risk is left to investors

(who can handle it best),

+ gives flexibility when used correctly,

+ no amortization costs,

- the investor's yield demand is higher than lender's (especially in specialized property),
- financial / synthetic leases are on-balance sheet in the future,

- loss of possible capital growth,

- loss of depreciation tax shields,

- exposure to rental property market risk,

- possible agency problems.

In general, arguments for and against debt funding are:

+ possibility to participate in upside of market / residual risk,

+ diversifies corporate asset portfolio,

+ lender's rate of return is lower than investor's,

+ option to sell and lease back,

+ security,

+ depreciation tax shields,

- release $<100 \%$ of value,

- less flexible than leasing,

- cash tied up to less liquid property assets,

- the balance sheet impacts,

- the risk of residual / market,

- need to provide for amortization over loan term.

\subsection{The common techniques in CRE finance}

It seems like the ongoing downsizing in many corporations, the fast development of property services cluster and the current high demand of good quality property investments have all had an impact on the amount of property outsourcings, which has been increasing steadily during the past years. Nevertheless, the basic reasons that have been introduced in the previous studies have been the rise of the shareholder value orientation and the increased competition between corporations.

The main characteristics of the property disposals in Europe during 98-03 have been among others the following:

- Leases have been quite long and properties quite important to the corporations.

- Outsourcing of specialized/single use real estate has been rather rare.

- Large part of the transactions has been done in the UK. 
- Total outsourcing of real estate and related services have been carried out, in practice, only in the UK.

- Most of the transactions have done by corporations that traditionally have large real estate holdings (retail, hotel), corporations under financial distress (telecom, airline) and former or current governmental corporations.

- In many cases, the buyers have used debt securitization to refinance their investments.

- Also joint ventures between occupiers, investment banks and property companies have been a popular way to divest corporate real estate.

The following picture summarizes the commonly used corporate real estate financing techniques that have been introduced in the academic literature during the past few years.

According to Krzysko and Marciniak (2001), Direct corporate funding (or corporate borrowing) would be most appropriate for properties that are unique to a corporation's operation. Firstly, it is clear that the difference between lender's and investor's required rate of return is highest when the property is very specialized. In addition, the real estate investor's ability to run real estate business better than the occupier often is the smaller the more specialized the property is. It may even be that the occupier is the best expert when it comes to specialized property.

Also secured lending is a way to get access to low-cost funds and the corporation can benefit from the possible appreciation (Wainwright 2000). However, in secured lending the property must be fairly typical and not specialized, because the lender is concerned with the underlying real estate security for the loan (Krzysko and Marciniak 2001). Debt securitization represents another increasingly important debt financing alternative. In debt securitization, mortgage loans are converted into tradable securities, backed by the steady rental income stream from the leased real estate (Nappi-Choulet 2002). Thus, it resembles secured lending with the difference that there is ultimately a large number of lenders and the collateral is usually not the real estate but the rental income stream. For instance Harrods and Marks\&Spencer have refinanced some of their property holdings by issuing bonds backed by the future rental cash-flows of their corporate real estate.

Joint Ventures are a good way to get access to property investor's / developer's property industry knowledge and, at the same time, share the risks and returns of the ownership. Krzysko and Marciniak (2001) write that real estate with highest upside potential is best suited for this. In development projects where the occupier can directly influence on the project's success just by leasing space, or in situations in which by leasing space the occupier can increase certain area's appreciation, are ideal for joint ventures. Lately many corporations have been using different joint venture structures also in property

\section{Solutions}

\begin{tabular}{|l|c|c|c|c|c|c|}
\hline Corporate borrowing & $\begin{array}{c}\text { Secured lending/ } \\
\text { Securitization }\end{array}$ & Synthetic Lease & $\begin{array}{c}\text { Indirect Vehicles, } \\
\text { Joint Venture }\end{array}$ & Bond net lease & Conventional lease & Total Outsourcing \\
\hline Sources of capital & Banks/Bond markets & Banks / Bond markets & $\begin{array}{c}\text { Propertycompanies, } \\
\text { institutions, other } \\
\text { investors }\end{array}$ & $\begin{array}{c}\text { Property companies, } \\
\text { institutions }\end{array}$ & $\begin{array}{c}\text { Property companies, } \\
\text { institutions }\end{array}$ & $\begin{array}{c}\text { PFIConsortia, all the } \\
\text { before mentioned }\end{array}$ \\
\hline \begin{tabular}{c} 
Bond markets \\
\hline
\end{tabular} & ONBALANCESHEET BankANC SHEET \\
\hline
\end{tabular}

Figure 1. Common techniques to finance corporate real estate, based mainly on Krzysko and Marciniak (2001), Wainwright (2000), Graff (2001) and JLL (2001) 
outsourcings. For instance, Tesco structured three joint ventures during 1996-1999 with property investment company British Land. British Land has formed joint ventures also with other owner-occupiers such as House of Fraser (1999) and Scottish \& Newcastle (1995). In addition, at least Telecom Italia and Deutsche Telecom have used joint venture structures in their property disposal schemes. A joint venture can be off-balance sheet finance, depending on the occupier's size of ownership and country's legislation.

Synthetic lease leaves all the property management responsibility and both the upside and downside residual risk to the occupier, which means that it resembles a lot normal senior debt funding (Graff 2001). The synthetic leases are currently off-balance sheet finance and usually best suited for properties that will consistently maintain a high level of value and are only required for a relatively short period (Krzysko and Marciniak 2001). Synthetic leases were common in the US during the 1990s, but lately they have become a less attractive financing method. This is mostly because the Financial Accounting Standards Board (FASB) is now looking into changing the rules that allow off-balance-sheet accounting for the leases, partly due to the accounting scandals of Enron and Worldcom. Also the new accounting standards in Europe (IFRS/IAS) that will be taken into use in 2005 will change the current rules that allow off-balance sheet financing of assets in most of the European countries. In the future, most of the synthetic lease structures will be classified as on-balance sheet finance in Europe.

In Bond net leases the tenant's credit is used directly to obtain borrowing capacity with little regard to the real estate. Krzysko and Marciniak (2001) write that this structure can be utilized for any substantial lease as a vehicle to lower cost. Leases are usually long and all the property management responsibilities and related risks are left to the occupier similarly as in synthetic leases (Graff 2001). However, when synthetic leases always include terms that leave both the upside and downside residual risks to the occupier, the bond net leases do not (Graff 2001). This is why bond net leases have replaced synthetic leases as the most important off-balance-sheet lease structure in the US. In the future leases that transfer residual risks back to the occupier are likely to be on-balance sheet. However, it is not certain if long net-leases are left off-balance sheet if the lease period is close to the property's economical life span under the IFRS/IAS rules.

Traditional leases are best used when properties that meet the business unit's needs are generally available in the market and when the corporation requires flexibility.

Total outsourcing means outsourcing corporation's real estate holdings combined with longterm property / facility management contracts. In this case, the corporation simply intends to withdraw entirely from real estate business. So far, the only clear example of total outsourcing in the private sector has been the British Telecom deal. In the public sector, there have been many examples in the UK.

\section{CONCLUSIONS}

In modern shareholder value based corporate governance culture, the markets tend to understand the value enhancement as maximizing company's asset base by focusing on the corporation's core competencies, which are usually the areas where the corporations can create the largest added value. Even though there is evidence that stock markets appreciate operational corporate real estate disposals, nearly $50 \%$ of the value of the real estate sale and leasebacks during 1998-2003 has been carried out by corporations under serious financial distress. Other corporate sectors that have been amongst this trend are hotels operators, retailers and other corporations with large freehold real estate base. In addition, current and former governmental corporations form approx. 2/3 of the corporations.

There is, however, clear evidence that by restructuring corporate real estate holdings and 
asset management corporations can usually cut costs, decrease risks related to corporate real estate functions and increase revenue stream by creating better support to the core business. Researchers have shown a number of times that corporate real estate holdings are often under managed and that corporations with a large freehold real estate base are outperformed by ones, which have looked at rationalizing their portfolio (for example Kuruvilla 1994, Rodney 2000). However, this can be done in many ways and only a few corporations have decided to leave real estate sector entirely.

It is known that corporate real estate often needs multiple strategies because of the multiple factors concerning products and markets that need to be supported (Nourse and Roulac 1993). Therefore, it is clear that the optimal technique to finance corporate real estate differs between asset types and uses as for example Krzysko and Marciniak (2001) have shown. In addition, corporation's own distinctive features and the overall market situation have a significant influence on what financing techniques a corporation should use.

It is important to decide clearly which property related risks corporation can bear efficiently. If the corporation transfers risks that it could handle better than service providers, it pays for nothing. Furthermore, when rushed, corporate real estate disposals can create more problems than they solve. For example, long lease agreements on wrong properties could create inflexibility. In addition, as in Modigliani and Miller's theories of agency problems between shareholders and corporate management, there could arise similar problems with service subscribers and providers. It is also important to remember that the rules for offbalance sheet financing are changing rapidly and therefore obtaining off-balance sheet finance cannot be the main reason for real estate sell-offs.

When done correctly disposals of operational corporate real estate can be a useful method in the process of unlocking inefficiencies and creating strategic advantages. It is usually not only possible to cut costs and improve key performance ratios with disposals, but disposals can also be an efficient way to finance corporate activities without increasing leverage levels. By outsourcing corporate real estate and related services to a professional service provider, the corporation can also get an access to property industry knowledge that it would not otherwise get. In addition, a professional property manager can often provide services more efficiently than an in-house organization, which can make outsourcing more cost effective than is commonly believed.

In future studies, it would be interesting to see empirical evidence on how the disposals of operational corporate real estate have succeeded and what could be learned in the future from these disposals. In addition, it would be interesting to see for example interview results on what have the true immediate reasons for the disposals been in different companies.

\section{REFERENCES}

Allen, M.T., Rutherford, R.C. and Springer, T.M. (1993) The wealth effects of corporate real estate leasing. Journal of Real Estate Research, $8(4)$, p. $567-578$.

Alvayay, J.R., Rutherford, R.C. and Smith, W.S. (1995) Tax-rules and sale and leasebacks of corporate real estate. Real Estate Economics, 23(2).

Ball, J.N., Rutherford, R.C. and Shaw, R.J. (1993) The wealth effects of real estate spin-offs. Journal of Real Estate Research, 8(4), p. 597606.

Benjamin, J.D., De La Torre, C. and Musumeci, J. (1998) Rationales for real estate leasing versus owning. Journal of Real Estate Research, 15(3), p. 223-237.

Booth, M., How corporate real estate affects shareholder value? (1999) Journal of Corporate Real Estate. 2(1), p. 19-28.

Chen, A.H., Conover, J.A. and Kensinger, J.W. (2002) Proven ways to increase shareholder value? Journal of Applied Finance, 12(1), p. 89-97.

Copeland T.E. and Weston F.J. (1992) Financial theory and corporate policy.

Copeland T., Koller T. and Murrin J. (2000) Valua- 
tion, Measuring and managing the values of companies.

Glascock, J.L., Davidson, W.N. and Sirmans, C.F. (1989) An Analysis of the acquisition and disposition of real estate assets. Journal of Real Estate Research, p. 131-140.

Graff R.A. (2001) Off-balance-sheet corporate finance with synthetic leases, shortcomings and how to avoid them with synthetic debt. Journal of Real Estate Research, 22(1/2), p. 213-241.

Hite, G.L., Owers, J.E. and Rogers, R.C. (1984) The Separations of real estate operations by spinoff. AREUEA Journal, 12(3), p. 318-332.

John, T.A. (1993) Optimality of spin-offs and allocation of debt. Journal of Financial and Quantitative Analysis, 28(1), p. 139-160.

Jones Lang LaSalle. (2001) European Capital Markets.

Krumm P. (1999) Corporate Real Estate Management in Multinational Corporations: A Comparative Analysis of Dutch Corporations, PhD Thesis published by Arko Publishers.

Krzysko G. and Marciniak C. (2001) Optimising real estate finance. Journal of Corporate Real Estate, 3(3), p. 286-298.

Kuruvilla, J. (1994) Corporate real estate holdings and the value of the firm, an empirical investigation.

Lewellen, W., Long, M.and McConnell, J. (1976) Asset leasing in competitive capital markets. Journal of Finance, 31, p. 787-798.

Manning, C. (1991) Leasing versus purchase of corporate real property: Leases with residual equity interests. Journal of Real Estate Research, 6(1), p. 79-85.

Megginson, W.L. (1997) Corporate finance theory.

Miller, M and Upton C. (1976) Leasing, buying and the cost of capital of services. Journal of Finance, 31, p. 761-786.

Myers, S., Dill, D. and Bautista, A. (1976) Valuation of financial lease contracts. Journal of Finance, 31, p. 799-820.

Nappi-Choulet, I. (2002) Corporate property outsourcing in Europe: Present trends and new approach for real estate economics, IPD European property strategies conference $16^{\text {th }}$ and $17^{\text {th }}$ May 2002 in Wiesbaden.

Nourse, H.O. and Roulac, S.E. (1993) Linking real estate decisions to corporate strategy. Journal of Real Estate Research, 8(4), p. 475-494.

Rodney, W. (2001) Enhancing corporate value through property re-engineering: Summary of main findings, City University of London Business School.

Rodriguez, M., Roulac, S.E. and Manning, C. (1997)
Which corporate real estate functions should be outsourced? Journal of Real Estate Research, 14(3), p. 259-274.

Rodriquez, M. and Sirmans, C.F. (1996) Managing corporate real estate: Evidence from the capital markets. Journal of Real Estate Literature, 4(1), p. 13-33.

Roulac, S.E. (2001) Corporate property strategy is integral to corporate business strategy. Journal of Real Estate Research, 22(1/2), p. 129-152.

Rutherford, R.C. (1990) Empirical evidence on shareholder value and the sale and leaseback of corporate real estate. AREUEA journal, 18(4), p. 522-529.

Rutherford, R.C. and Nourse, H.O. (1988) The impact of corporate real estate unit formation on the parent firm's value. Journal of Real Estate Research, 3(4), p. 73-84.

Slovin, M.B, Sushka, M.E. and Polonchek, J.A (1990) Corporate sale and lease back and shareholder wealth. Journal of Finance, 45(1), p. 289-299.

Stulz, R. and Johnson H. (1985) An analysis of secured debt. Journal of Financial Economics, 14, p. 501-521.

Wainwright S. (2000) Off-balance-sheet property ownership structures, releasing capital from operational portfolios through divestment. Journal of Corporate Real Estate, 2(4), p. 330-342.

Woolridge, J.R. (1995) Do stock prices reflect fundamental values? Journal of Applied Corporate Finance. 
Appendix: Major sale and leasebacks in Europe 98-03 (publicly available information)

Table 3. Major real estate sale and leasebacks in Europe 1998-2003

\begin{tabular}{|c|c|c|c|c|}
\hline Seller & Country of origin & Year & $\begin{array}{l}\text { Value } \\
\text { mEUR }\end{array}$ & Buyer \\
\hline Kesko & Finland & 1998 & 200.0 & Citycon (2 transactions) \\
\hline Tesco & UK & 1998 & 155.8 & British Land (Tesco owns majority of the joint venture) \\
\hline Kesko & Finland & 1999 & 135.6 & Castrum and Citycon ( 2 transactions) \\
\hline Tesco & UK & 1999 & 527.6 & British Land (Tesco owns majority of the joint venture) \\
\hline MFI & UK & 1999 & 154.4 & MEPC \\
\hline House of Fraser & UK & 1999 & 328.9 & British Land ( $\mathrm{H}$ of $\mathrm{F}$ owns majority of the joint venture) \\
\hline Metro & Germany & 1999 & $2,700.0$ & Westdeutsche Landesbank \\
\hline WH Smith & UK & 1999 & 57.2 & LaSalle lnvestment Management \\
\hline Kesko & Finland & 2000 & 67.3 & Nordisk Renting \\
\hline Marks \& Spencer & UK & 2001 & 580.0 & Topland \\
\hline Somerfield & UK & 2001 & 39.6 & Hamilton Sherbum Syndicate \\
\hline Sainsbury & UK & 2001 & 557.0 & Morgan Stanley \\
\hline Carrefour & France & 2001 & $2,040.0$ & Klepierre, Corte Ingles and Eroski ( 2 transactions) \\
\hline Kingfisher (Woolworths) & UK & 2001 & 990.0 & London \& Regional and Whitehall Funds \\
\hline Somerfield & UK & 2002 & 83.8 & Royal \& Sun and Prudential Assurance ( 2 transactions) \\
\hline Carrefour & France & 2002 & 105.0 & W.P. Carey \& Co \\
\hline Stockmann Oyj & Finland & 2002 & 32,2 & Nordea Life Insurance \\
\hline Stockmann Oyj & Finland & 2003 & 36.0 & Wereldhave \\
\hline Rexel Group & France & 2003 & 41.0 & Ashtenne \\
\hline Marks \& Spencer & UK & 2003 & 164.0 & Gracechurch Property Limited \\
\hline MFI & UK & 2003 & 37.2 & Chance Asset Management \\
\hline Carrefour & France & 2003 & 10.3 & W.P. Carey \& Co \\
\hline ICA & Sweden & 2003 & 335.2 & London \& Regional, GE Real Estate and Eurocommercial ( 2 deals) \\
\hline Retail and trade, total & & & $9,345.9$ & $23.2 \%$ \\
\hline UBS Warburg & Switzerland & 1999 & 513.2 & Consortium led by Maag Holdings Ltd \\
\hline Abbey National & UK & 2000 & 656.9 & Mapeley (owned by Fortress, Soros Real Estate and Delancey) \\
\hline JP Morgan & US (properties in UK) & 2000 & 358.1 & London \& Regional \\
\hline Banca di Roma & Italy & 2001 & 568.0 & Morgan Stanley and Pirelli \& Co \\
\hline Deutsche Bank & Germany & 2003 & 328.9 & KanAm Grundinvest Fonds and British Land \\
\hline Nordea & The Nordic countries & 2003 & 500.0 & PKA, PensionDanmark, LPK, Nordea Pension and LXIS AEW (3 deals) \\
\hline Banking and finance, tota & & & $2,925.1$ & $7.3 \%$ \\
\hline Shell & Netherlands / UK & 1999 & 428.9 & London \& Regional and Rotch \\
\hline Conoco & UK & 1999 & 52.9 & Wereldhave \\
\hline EDF & France & 2000 & 773.0 & Selec / Deutsche Bank \\
\hline EDF & France & 2001 & 884.0 & Morgan Stanley, Foncière des Regions, Unibail and SNI \\
\hline Gas Natural & Spain & 2001 & 47.0 & Unibai! \\
\hline Suez & France & 2003 & 300.0 & GE Capital Real Estate \\
\hline Oil and Energy, total & & & $2,485.8$ & $6.2 \%$ \\
\hline Telecom Italia & Italy & 2000 & $2,900.0$ & Lehman Brothers and Beni Stabili ( $\mathrm{Tl}$ owns $40 \%$ of the joint venture) \\
\hline Ericsson & Sweden & 2000 & 403.6 & AP Fastigheter, Kungsleden and Drott ( 3 transactions) \\
\hline Thomson Multimedia & France & 2000 & 91.0 & Société Foncière Lyonnaise \\
\hline British Telecom & UK & 2001 & $3,800.0$ & Land Securities Trillium and William Pears Group \\
\hline Marconi & UK & 2001 & 94.4 & St Modwen Properties and Salia Real Estate \\
\hline France Telecom & France & 2001 & $3,300.0$ & Goldman Sachs, GE Capital and CDC Ixis \\
\hline Deutsche Telecom & Germany & 2001 & $1,100.0$ & Morgan Stanley and Corpus (DT owns $51 \%$ of the joint-venture) \\
\hline SwissCom & Switzerland & 2001 & $1,635.7$ & CSFB, PSP Swiss Property and Lehman Brothers ( 2 deals) \\
\hline Ericsson & Sweden & 2001 & 27.2 & Andrew Bars \& Co and Andrew Mayer \\
\hline Marconi & UK & 2002 & 28.6 & British Land \\
\hline France Telecom & France & 2002 & 510.0 & Morgan Stanley and Foncière des Régions \\
\hline \multicolumn{2}{|l|}{ IT and electronics, total } & & $13,890.5$ & $34.4 \%$ \\
\hline
\end{tabular}




\begin{tabular}{|c|c|c|c|c|}
\hline Fiat & Italy & 1998 & 216.0 & Morgan Stanley \\
\hline Thales & France & 2001 & 46 & Deutsche Bank \\
\hline Alstom group & France & 2002 & 158.7 & Key Property Investments \\
\hline $\mathrm{ABB}$ & Switzerland & 2002 & 256.6 & London \& Regional \\
\hline $\mathrm{NCC}$ & Sweden & 2002 & NA & Goldman Sachs / Whitehall Funds \\
\hline Outokumpu Oyj & Finland & 2002 & 50.0 & Varma-Sampo \\
\hline Jaakko Pбугy Oyj & Finland & 2003 & 48.0 & Nordisk Renting (owned by Royal Bank of Scotland) \\
\hline Alstom group & France & 2003 & 120.5 & CDC IXIS Capital markets \\
\hline \multicolumn{3}{|c|}{ Engineering and construction, total } & 895.8 & $2.2 \%$ \\
\hline TBI & UK & 1999 & 286.5 & London \& Regional \\
\hline Deutsche Bahn & Germany & 2000 & $2,600.0$ & Nomura and WCM \\
\hline Svenska Posten & Sweden & 2001 & 407.4 & Wihlborgs and AP Fastigheter \\
\hline Deutsche Post & Germany & 2001 & $5,100.0$ & Many buyers during 1997-2002 \\
\hline BBC & UK & 2001 & 369.0 & Land Securities Trillium \\
\hline SAS & Sweden, Denmark, Norway & 2001 & 334.4 & GE Real Estate and Nordisk Renting (owned by RBS) \\
\hline SAS & Sweden, Denmark, Norway & 2003 & 110.7 & Keops \\
\hline \multicolumn{3}{|c|}{ Governmental and transportation, total } & $9,208.0$ & $22.8 \%$ \\
\hline First leisure & UK & 2001 & 121.8 & London \& Regional \\
\hline The Hilton Group & UK & 2001 & 448.0 & The Royal Bank of Scotland \\
\hline The Hitton Group & $\mathrm{UK}$ & 2002 & 480.4 & Rotch, Famsworth and RBS (Hilton owns $40 \%$ of the joint venture) \\
\hline Jarvis Hotels & UK & 2002 & 214.4 & Large number of private investors \\
\hline Accor & UK & $2001-03$ & 286.5 & London \& Regional \\
\hline Mèdica France & France & 2003 & 43.0 & W.P. Carey \& Co \\
\hline \multicolumn{3}{|c|}{ Hotels, leisure and residential, total } & $1,594.1$ & $4.0 \%$ \\
\hline \multicolumn{3}{|c|}{ ALL BUSINESS SECTORS, TOTAL } & $40,345.2$ & $100.0 \%$ \\
\hline
\end{tabular}

